\title{
Changing Dietary Cation-Anion Difference for Dairy Cows Fed with Two Contrasting Levels of Concentrate in Diets
}

\author{
E. Apper-Bossard, ${ }^{\star}$ J. L. Peyraud, ${ }^{\star 1}$ P. Faverdin, ${ }^{*}$ and F. Meschy ${ }^{\star} \dagger$ \\ *Unité Mixte de Recherches INRA-Agrocampus Production du Lait, Domaine de la Prise, 35590 Saint-Gilles, France \\ †Unité Mixte de Recherches, INRA-INAPG Physiologie de la Nutrition et Alimentation, INRA-INAPG, \\ 16 rue Claude Bernard, F-75231 Paris Cedex 05, France
}

\begin{abstract}
High-producing dairy cows are commonly fed diets containing a high proportion of rapidly degradable starch, which can cause subacute acidosis and reduce dry matter (DM) intake. Because of the properties of nonmetabolizable cations and anions, increasing the dietary cation-anion difference $(\mathrm{DCAD}=\mathrm{Na}+\mathrm{K}-\mathrm{Cl}$ $-\mathrm{S}$ in $\mathrm{mEq} / \mathrm{kg}$ of $\mathrm{DM}$ ) may prevent a drop in $\mathrm{DM}$ intake. To test this hypothesis, 48 Holstein cows were blocked into 2 groups of 24 and assigned to two $3 \times 3$ Latin squares in a split-plot design. Each group received one level of concentrate at either $20 \%$ or $40 \%$ on a dry matter (DM) basis. The diet containing $20 \%$ concentrate was formulated to supply $4 \%$ rapidly degradable starch, whereas the diet containing $40 \%$ concentrate supplied $22 \%$ rapidly degradable starch. Diets in each square were formulated to provide a DCAD of 0,150 , or 300 $\mathrm{mEq} / \mathrm{kg}$ of DM. The 3 values were obtained by manipulating $\mathrm{Na}$ and $\mathrm{Cl}$ contents. Intake, $4 \%$ fat-corrected milk yield, and milk fat percentage, as well as blood nonesterified fatty acids and $\beta$-hydroxybutyrate increased with DCAD, but only on the diet providing $40 \%$ concentrate. The yield of trans-10 $\mathrm{C}_{18: 1}$ and odd-chain fatty acids decreased with increasing DCAD, whereas trans$11 \mathrm{C}_{18: 1}$ increased. Again, this occurred only with the diet providing $40 \%$ concentrate. Blood $\mathrm{pH}$ and $\mathrm{HCO}_{3}$ concentration increased along with DCAD, irrespective of the concentrate level. A positive DCAD led to increasing DM intake and fat-corrected milk yield in dairy cows fed highly degradable diets. The mechanism involved may be a localized rumen buffering effect, together with the ability of positive DCAD to maintain blood acid-base status in cows faced with a massive acid input.
\end{abstract}

Key words: dietary cation-anion difference, performance, acid-base status, dairy cow

Received December 14, 2004.

Accepted July 1, 2005.

${ }^{1}$ Corresponding author: jean-louis.peyraud@rennes.inra.fr

\section{INTRODUCTION}

High-producing dairy cows are commonly fed highly digestible diets containing a high proportion of rapidly degradable starch. Obvious drawbacks to this strategy are the subsequent decrease in ruminal $\mathrm{pH}$, increase in the production of VFA, an increase in propionate production, and an alteration in rumen biohydrogenation of dietary polyunsaturated fatty acids, which, in turn, reduces milk fat synthesis (Doreau et al., 1999; Bauman and Griinari, 2003). Moreover, several experiments have reported changes in blood acid-base status that were correlated with changes in ruminal environment. Faverdin et al. (1999) showed that blood $\mathrm{HCO}_{3}$ concentration and blood base excess were negatively correlated with the concentration of VFA in ruminal fluid when large amounts of rolled wheat were added into the rumen of dairy cows. This finding was accompanied by a transient reduction in DMI. Other studies have reported a marked decrease in blood $\mathrm{HCO}_{3}$ concentration and base excess during subacute rumen acidosis in steers (Goad et al., 1998). Therefore, in agreement with Owens et al. (1998), we can assume that, with highly degradable diets, a higher proportion of $\mathrm{HCO}_{3}$ can be derived from the blood, thus causing a decrease in blood base excess.

A large DCAD, defined as milliequivalents of $(\mathrm{Na}+$ $\mathrm{K}-\mathrm{Cl}-\mathrm{S}$ ) per kilogram of DM (Tucker et al., 1991), should assist in preventing metabolic acidosis because the absorption of $\mathrm{Na}$ and $\mathrm{K}$ will increase blood $\mathrm{HCO}_{3}$ concentration (Stewart, 1983). A large positive DCAD could also alter ruminal fermentation and increase ruminal $\mathrm{pH}$, as suggested by Roche et al. (2005). There is some evidence that milk yield, fat yield, and DMI increase along with DCAD in early and mid-lactating dairy cows fed high-grain and low-roughage diets (Tucker et al., 1988; West et al., 1991).

The effect of increased DCAD on the cow's performance may differ according to the proportion and type of concentrate in the diet. Increasing DCAD could be more efficient when concentrates rich in rapidly degradable starch make up a high proportion of the diet offered to dairy cows, because of either direct ruminal 
buffering or a systemic buffering effect. Consequently, the target level of DCAD may depend on the concentrate-to-forage ratio of the diet. In the present study, we aimed to test this hypothesis by examining the effects of increasing DCAD from 0 to $300 \mathrm{mEq} / \mathrm{kg}$ of DM on DMI, milk production, and acid-base status in lactating dairy cows receiving diets with different roughage-to-concentrate ratios.

\section{MATERIALS AND METHODS}

\section{Experimental Design}

The trial was conducted using a split-plot design with 48 Holstein cows. Cows were assigned to 2 groups of 24 according to parity (6 primiparous and 18 multiparous animals), stage of lactation (105 \pm 22 DIM), milk production $(29.2 \pm 4.0 \mathrm{~kg} / \mathrm{d})$, milk protein $(3.16 \pm$ $0.25 \%)$, fat content $(4.23 \pm 0.46 \%)$, and BW (624 \pm $60 \mathrm{~kg}$ ). Each group of cows received 1 of 2 levels of concentrate during the trial. Within each group, cows were assigned to 3 planned levels of DCAD. The cows were assigned to 4 blocks of 6 and within each block the cows received the 3 levels of DCAD according to a $3 \times 3$ balanced Latin square design. The trial included a 2 -wk period of adaptation to the basal diet, followed by 3 measurement periods of $4 \mathrm{wk}$ each.

\section{Treatments and Feeding}

Six diets were formulated with various different levels of concentrate and DCAD (Table 1). The low-concentrate diets (LC) consisted of $21 \%$ concentrate and minerals and $79 \%$ corn silage on a DM basis. The highconcentrate diets (HC) consisted of $41 \%$ concentrate and minerals and 59\% corn silage. The 3 planned DCAD levels were 0 (LD), 150 (MD), and $300($ HD) $\mathrm{mEq} / \mathrm{kg}$ of DM. The 6 experimental diets were 1) low concentrate with low DCAD (LCLD), 2) low concentrate with medium DCAD (LCMD), 3) low concentrate with high DCAD (LCHD), 4) high concentrate with low DCAD (HCLD), 5) high concentrate with medium DCAD (HCMD), and 6) high concentrate with high DCAD (HCHD).

Two energy concentrates were formulated to maximize the difference in rapidly degradable starch (wheat and barley) between the 2 groups of diets (Table 1). The centesimal compositions on a DM basis of the 2 concentrates are shown in Table 1 . Because the DCAD of grain was approximately zero, dehydrated alfalfa and molasses were added to the concentrate in the $\mathrm{HC}$ diet to ensure similar DCAD for the 2 diets before adding the experimental mineral mixture. Finally, for the LC and HC diets, respectively, the proportions of highly fermentable cereals were 3.7 and
$21.5 \%$ DM. The respective proportions of ADF were 18.6 and $16.2 \% \mathrm{DM}$, and the proportions of NDF were 35.7 and $31.4 \%$. In the LD and HD diets, NDF originating from corn silage accounted for 30.4 and $22.7 \%$, respectively.

Differences in DCAD values were obtained by manipulation of dietary $\mathrm{Na}$ and $\mathrm{Cl}$. Two mineral mixtures were used to set the medium and high DCAD levels. The ingredients of the 2 mineral mixtures are shown in Table 1. Low DCAD was obtained by adding $0.8 \%$ $\mathrm{NH}_{4} \mathrm{Cl}$ to the MD diets (Table 1). High DCAD was obtained by replacing $\mathrm{CaCO}_{3}$ by $\mathrm{NaCO}_{3}$ and $\mathrm{Na}_{2} \mathrm{PO}_{4}$. With increasing DCAD, Na content increased from 0.21 to $0.50 \% \mathrm{DM}$, whereas $\mathrm{Cl}$ content decreased from 1.05 to $0.45 \% \mathrm{DM}$ (Table 1). The concentrations of other minerals were kept constant to ensure that the observed effects could be attributed to the manipulation of $\mathrm{DCAD}$. The $\mathrm{K}, \mathrm{S}, \mathrm{Ca}, \mathrm{P}$, and $\mathrm{Mg}$ contents averaged $1.15,0.12,0.77,0.33$, and $0.19 \% \mathrm{DM}$, respectively. The S content was low because of the corn silage, which contained only $0.62 \mathrm{~g}$ of $\mathrm{S} / \mathrm{kg}$ of DM.

The diets were formulated to supply similar amounts of $\mathrm{NE}_{\mathrm{L}}(1.57 \mathrm{MCal} / \mathrm{kg}$ of DM), total CP content $(14.5 \% \mathrm{DM})$, and digestible protein in the intestine (PDI, $95.6 \mathrm{~g} / \mathrm{kg}$ of DM) to meet energy, protein, Ca, and $\mathrm{P}$ requirements (Institut National de la Recherche Agronomique, 1989). The diets were supplemented with urea to cover $105 \%$ of the microbial requirements of degradable $\mathrm{N}$.

Corn silage, concentrate, and mineral supplements were mixed in 6 different TMR. The cows were fed individually to ensure ad libitum intake (allowing more than $10 \%$ orts) twice daily at 0900 and $1600 \mathrm{~h}$ (50:50). Cows were housed in free stalls. To control mineral supply, no straw or mineral blocks were provided. Cows were milked twice daily at 0700 and 1730 $\mathrm{h}$ and weighed once a week.

\section{Sampling Schedule and Procedure}

Feeds and Orts. Voluntary DMI was individually recorded daily during the experiment using an individual electronic gate. The DM content of corn silage was determined $\left(80^{\circ} \mathrm{C}, 48 \mathrm{~h}\right)$ every $3 \mathrm{~d}$ to adjust the proportion of corn silage in the diets. Orts were collected and weighed daily before the morning feeding. To calculate DMI, the composition of orts was assumed similar to the offered diet. For chemical analyses, oven-dried samples of corn silage were pooled over each period, whereas concentrates and mineral mixtures were sampled weekly, and the samples were pooled over the whole experimental period. All samples were ground with a 3-blade knife mill through a $0.8-\mathrm{mm}$ screen. Organic matter content was determined by ashing at 
Table 1. Composition (\% DM) and nutrients (calculated from analyzed values, units are all g/100 g of DM unless stated otherwise) of experimental diets

\begin{tabular}{|c|c|c|c|c|c|c|}
\hline \multirow[b]{2}{*}{ Diets } & \multicolumn{6}{|c|}{ Treatment $^{1}$} \\
\hline & LCLD & LCMD & LCHD & HCLD & HCMD & HCHD \\
\hline Corn silage & 78.6 & 79.0 & 79.0 & 58.6 & 59.0 & 59.0 \\
\hline LC concentrate ${ }^{2}$ & 17.0 & 17.0 & 17.0 & - & - & - \\
\hline $\mathrm{HC}$ concentrate ${ }^{3}$ & - & - & - & 37.0 & 37.0 & 37.0 \\
\hline HD mineral mixtures ${ }^{4}$ & - & - & 3.0 & - & - & 3.0 \\
\hline LD and MD mineral mixtures 5 & 3.0 & 3.0 & - & 3.0 & 3.0 & - \\
\hline $\mathrm{NH}_{4} \mathrm{Cl}$ & 0.8 & - & - & 0.8 & - & - \\
\hline Urea & 0.6 & 1.0 & 1.0 & 0.6 & 1.0 & 1.0 \\
\hline \multicolumn{7}{|l|}{ Nutrients } \\
\hline $\mathrm{CP}$ & 14.6 & 14.5 & 14.4 & 14.3 & 14.7 & 14.2 \\
\hline $\mathrm{PDIE},{ }^{6} \mathrm{~g} / \mathrm{kg}$ & 97.2 & 97.5 & 96.8 & 95.4 & 95.7 & 95.0 \\
\hline $\mathrm{PDIN},{ }^{7} \mathrm{~g} / \mathrm{kg}$ & 96.9 & 96.2 & 95.5 & 94.4 & 93.8 & 93.1 \\
\hline $\mathrm{NE}_{\mathrm{L}}, \mathrm{Mcal} / \mathrm{kg}$ & 1.56 & 1.56 & 1.56 & 1.58 & 1.58 & 1.58 \\
\hline $\mathrm{ADF}$ & 18.5 & 18.6 & 18.6 & 16.2 & 16.3 & 16.2 \\
\hline NDF & 35.6 & 35.8 & 35.7 & 31.3 & 31.5 & 31.4 \\
\hline Starch & 30.1 & 30.1 & 30.1 & 36.6 & 36.6 & 36.6 \\
\hline $\mathrm{Ca}$ & 0.74 & 0.74 & 0.74 & 0.79 & 0.79 & 0.79 \\
\hline $\mathrm{P}$ & 0.32 & 0.32 & 0.31 & 0.34 & 0.34 & 0.33 \\
\hline $\mathrm{Mg}$ & 0.19 & 0.19 & 0.19 & 0.20 & 0.20 & 0.19 \\
\hline $\mathrm{S}$ & 0.11 & 0.11 & 0.10 & 0.13 & 0.12 & 0.12 \\
\hline $\mathrm{Na}$ & 0.20 & 0.21 & 0.50 & 0.21 & 0.21 & 0.50 \\
\hline $\mathrm{K}$ & 1.13 & 1.14 & 1.13 & 1.17 & 1.17 & 1.16 \\
\hline $\mathrm{Cl}$ & 1.02 & 0.51 & 0.41 & 1.07 & 0.56 & 0.47 \\
\hline $\mathrm{DCAD}^{8}(\mathrm{Na}+\mathrm{K})-(\mathrm{Cl}+\mathrm{S})$ & 17 & 169 & 327 & 4 & 156 & 306 \\
\hline $\mathrm{ED}^{8}(\mathrm{Na}+\mathrm{K})-\mathrm{Cl}$ & 87 & 238 & 390 & 86 & 231 & 381 \\
\hline
\end{tabular}

${ }^{1} \mathrm{LCLD}=$ Low concentrate and low dietary cation-anion difference (DCAD); LCMD = low concentrate and medium DCAD; LCHD = low concentrate and high DCAD; HCLD = high concentrate and low DCAD; $\mathrm{HCMD}=$ high concentrate and medium DCAD; HCHD = high concentrate and high DCAD; DCAD expressed as $\mathrm{mEq} / \mathrm{kg}$ of $\mathrm{DM}(\mathrm{Na}+\mathrm{K})-(\mathrm{Cl}+\mathrm{S})$.

${ }^{2} \mathrm{On}$ a DM basis (\%): 21.5 barley, 44.2 formaldehyde-treated soybean meal, 32.3 soybean meal, and 2.0 distillery residues.

${ }^{3}$ On a DM basis (\%): 39.2 wheat, 20.2 barley, 13.5 formaldehyde-treated soybean meal, 13.5 soybean meal, 8.1 dehydrated alfalfa, and 5.5 molasses.

${ }^{4}$ Mineral mixture (in g/kg of DM): $474 \mathrm{CaCO}_{3}, 105 \mathrm{NaCl}, 0 \mathrm{CaPO}_{4}, 138 \mathrm{Na}_{2} \mathrm{PO}_{4}, 200 \mathrm{NaCO}_{3}, 30 \mathrm{MgO}, 3.6$ $\mathrm{ZnSO}_{4}, 2.7 \mathrm{MnSO}_{4}, 1.1 \mathrm{CuSO}_{4}, 0.03 \mathrm{CoSO}_{4}, 0.03$ Vitamins, 0.02 sodium selenite, 45 Corn.

${ }^{5}$ Mineral mixture (in g/kg of DM): $395 \mathrm{CaCO}_{3}, 158 \mathrm{NaCl}, 150 \mathrm{CaPO}_{4}, 0 \mathrm{Na}_{2} \mathrm{PO}_{4}, 0 \mathrm{NaCO}_{3}, 30 \mathrm{MgO}, 3.6$ $\mathrm{ZnSO}_{4}, 2.7 \mathrm{MnSO}_{4}, 1.1 \mathrm{CuSO}_{4}, 0.03 \mathrm{CoSO}_{4}, 0.03$ Vitamins, 0.02 Sodium selenite, 260 Corn.

${ }^{6}$ Digestible protein in the small intestine supplied by microbial protein from rumen-fermented OM (Institut National de la Recherche Agronomique, 1989).

${ }^{7}$ Digestible protein in the small intestine supplied by microbial protein from rumen-degraded protein (Institut National de la Recherche Agronomique, 1989).

${ }^{8} \mathrm{DCAD}$ and $\mathrm{ED}$ (electrolyte difference) were expressed in $\mathrm{mEq} / \mathrm{kg}$ of $\mathrm{DM}$.

$550^{\circ} \mathrm{C}$ for $6 \mathrm{~h}$. Feed $\mathrm{N}$ was determined by the Dumas method (Association Française de Normalisation, 1985a). Feed NDF and ADF were analyzed according to the method initially described by Van Soest et al. (1991). Starch was determined by Ewers' polarimetric method (Association Française de Normalisation, 1985b). Minerals (except P, Cl, and S) were measured by atomic absorption spectrophotometry (SpectraAA20, Varian, Les Ulis, France) after dry-ashing at $550^{\circ} \mathrm{C}$ (for $\mathrm{Ca}$ and $\mathrm{Mg}$ ) or $500^{\circ} \mathrm{C}$ (for $\mathrm{Na}$ and $\mathrm{K}$ ) for 12 h. The ash was acidified with $\mathrm{HCl}$ before analysis. The $\mathrm{P}$ concentration was measured using the alkalimeter ammonium molybdate method (AOAC, 1984). The Cl concentration was determined by potentiometric titration with silver nitrate (Compact titrator, Crison, Bar- celona, Spain). The $\mathrm{S}$ concentration was determined by gravimetry after drying at $525^{\circ} \mathrm{C}$ with an $\mathrm{MgNO}_{3}$ solution and precipitating with a $\mathrm{BaCl}$ solution.

Milk. Milk yield was recorded at each milking using electronic flow meters (Metatron 21, Westfalia, Germany). Protein and fat contents were determined by infrared analysis (Milkoscan, Foss Electric, Hillerød, Denmark) on individual samples collected on 6 successive milkings each week. For detailed milk analysis, 12 cows ( 2 per block) were chosen as representative of each block and were sampled at each period. On d 18 of each period, $250 \mathrm{~mL}$ of milk were taken at the morning milking for analysis of fatty acid composition and lactose and at the morning and evening milking for $\mathrm{Na}$, $\mathrm{K}$, and $\mathrm{Cl}$. The milk $\mathrm{pH}$ was measured, and the samples 
were stored immediately afterwards at $-20^{\circ} \mathrm{C}$ pending further chemical analysis. Lactose was analyzed according to Hurtaud et al. (1993). Milk fatty acids were analyzed by chromatography after extraction. Briefly, lipids were extracted from $1 \mathrm{~mL}$ of milk fat according to Bauchart and Duboisset (1983), using $0.5 \mathrm{~mL}$ of ethanol: $\mathrm{HCl}$ solution $(4: 1, \mathrm{vol} / \mathrm{vol})$ followed by $0.5 \mathrm{~mL}$ of hexane. Milk fatty acids were then transesterified by 2 methods. For fatty acid butyl esters, lipids were esterified with $1 \mathrm{~mL}$ of butanol:HCl solution (100:5, $\mathrm{vol} / \mathrm{vol}$ ), followed by $2 \mathrm{~mL}$ of hexane. For fatty acid methyl esters, lipids were esterified with $1 \mathrm{~mL}$ of methanol: $\mathrm{NaOH}$ solution $(100: 2, \mathrm{vol} / \mathrm{vol})$ followed by $0.5 \mathrm{~mL}$ of methanol boron trifluorure solution (100:20, vol/vol) and $2 \mathrm{~mL}$ of hexane. Fatty acid methyl ester was used to obtain the unsaturated fatty acid. Both fatty acid esters (butyl and methyl) dissolved in hexane were injected into a gas chromatograph (Varian 3400, Les Ulis, France) equipped with an electron ionization detector. The separation of fatty acid butyl esters was performed with an OV-1 fused silica capillary column $(25 \mathrm{~m} \times 0.32 \mathrm{~mm}$ i.d.). The oven temperature was programmed to rise from 70 to $220^{\circ} \mathrm{C}$ at $100^{\circ} \mathrm{C} / \mathrm{min}$. Injector and detector were at 220 and $250^{\circ} \mathrm{C}$, respectively (Rigout et al., 2002). Separation of fatty acid methyl esters was performed using an SP2560 (Supelco, Bellefonte, PA) fused silica capillary column (100 m $\times$ $0.25 \mathrm{~mm}$ i.d.) at a fixed temperature, $160^{\circ} \mathrm{C}$. Both injector and detector were at $230^{\circ} \mathrm{C}$. The carrier gas was helium. Among the conjugated linoleic acids, only cis9,trans-11 $\mathrm{C}_{18: 2}$ was identified with the column. Milk $\mathrm{Na}$ and $\mathrm{K}$ were analyzed by atomic absorption spectrophotometry (Spectra-AA20, Varian) after deproteinization of $10 \mathrm{~mL}$ of milk using $20 \mathrm{~mL}$ of distilled water, and $5 \mathrm{~mL}$ of TCA $20 \%$ (wt/vol). Milk Cl was analyzed by potentiometric titration (Compact titrimeter, Crison) after 1:10 dilution in distilled water.

Blood. Blood was collected on d 24 by coccygeal puncture at $0730 \mathrm{~h}$ before the beginning of the morning meal using 2.0-mL syringes for blood gases (S-Monovette; Sarstedt, Nümbrecht, Germany) and 7.5-mL syringes containing heparin at 12 to $30 \mathrm{IU} / \mathrm{mL}$ (S-Monovette; Sarstedt) for analysis of glucose, lactate, BHBA, NEFA, and urea. For blood gases and minerals, a second sample was taken at $1330 \mathrm{~h}$. Blood pH, blood $\mathrm{HCO}_{3}$ concentration, blood $\mathrm{CO}_{2}$ partial pressure $\left(\mathbf{p} \mathbf{C O}_{2}\right.$ ), standard base excess (SBE), blood hemoglobin, and blood minerals ( $\mathrm{Na}, \mathrm{K}, \mathrm{Cl}$, and $\mathrm{Ca}$ ) were immediately determined by potentiometry using a blood gas and mineral analyzer (ABL 330, OSM3, EML 105, Radiometer, Copenhagen, Denmark). For the analysis of metabolites, blood samples were centrifuged at $3000 \times g$ for $12 \mathrm{~min}$ at $4^{\circ} \mathrm{C}$. For lactate determination, $4 \mathrm{~mL}$ of plasma was deproteinized with $8 \mathrm{~mL}$ of perchloric acid.
Samples were stored at $-20^{\circ} \mathrm{C}$ before laboratory analysis. Plasma concentrations of metabolites were measured on a multiparameter analyzer (KONE Instruments Corporation, Espoo, Finland) using a kit for glucose (kit glucose hexokinase, Diagnostics, Meylan, France), a kit for lactate (ref. 61192, BioMerieux, Marcy L'Etoile, France), a kit for BHBA (RB 1007, Randox, Maugio, France), a kit for NEFA (NEFA C test, Wako, Oxoid, Davdilly, France), and a kit for urea (ref. 11703, Thermo Electron, Cergy-Pontoise, France).

\section{Statistical Analyses}

Intake, milk production, milk composition, and BW were calculated over the last 2 wk of each period. Energy and PDI balances were calculated from the mean value for each cow according to methods described by the Institut National de la Recherche Agronomique (1989). Data were analyzed using the GLM procedure of SAS (SAS Institute, 1990), according to the model for a split-plot design. The linear model used is described by the following equation:

$$
\begin{gathered}
\mathrm{Y}_{\mathrm{ijkl}}=\mu+\text { Conc }_{\mathrm{i}}+\mathrm{C}_{\mathrm{j}(\mathrm{i})}+\mathrm{D}_{\mathrm{k}}+\mathrm{P}_{\mathrm{l}}+\text { DConc }_{\mathrm{ki}} \\
+\operatorname{ConcP}_{\mathrm{i} l}+\mathrm{e}_{\mathrm{ijk}}
\end{gathered}
$$

where $Y_{i j k l}=$ variable studied during period; $\mu$ = overall mean of the population; Conc $_{i}=$ effect due to the concentrate level i (LC vs. HC; tested against the mean square of cow within the concentrate group effect); $\mathrm{C}_{\mathrm{j}(\mathrm{i})}=$ effect due to cow $\mathrm{j}$ fed diet $\mathrm{i} ; \mathrm{D}_{\mathrm{k}}=$ effect due to DCAD k; $\mathrm{P}_{1}=$ effect due to period $\mathrm{l} ; \mathrm{DConc}_{\mathrm{ki}}=$ interaction between DCAD and concentrate level; Conc $_{\text {il }}=$ interaction between concentrate and period; and $\mathrm{e}_{\mathrm{ijkl}}=$ error associated with each $\mathrm{Y}_{\mathrm{ijk} \mathrm{k}}$.

The sum of squares of the D and DConc effects were further partitioned into comparisons with a single degree of freedom to provide the linear and quadratic effects of DCAD and its interaction with the concentrate level using the orthogonal polynomial method (Gill, 1978). For the statistical analysis of blood gases, we determined 3 classes of blood from coccygeal sampling. We assumed that $\mathrm{O}_{2}$ saturation was higher than $95 \%$ in arterial blood and was lower than $75 \%$ in venous blood. Oxygen saturation values between 95 and $75 \%$ were considered representative of a mixture of arterial and venous blood (Shapiro et al., 1992).

\section{RESULTS}

\section{Blood Acid-Base Status}

Blood $\mathrm{pH}$, concentration of $\mathrm{HCO}_{3}, \mathrm{SBE}, \mathrm{pCO}_{2}$, and blood concentration of hemoglobin were not affected 
Table 2. Effects of DCAD and concentrate level on blood gases

\begin{tabular}{|c|c|c|c|c|c|c|c|c|c|c|c|}
\hline \multirow[b]{3}{*}{ Item $^{3}$} & \multirow{2}{*}{\multicolumn{6}{|c|}{ Treatment $^{1}$}} & \multirow[b]{3}{*}{ SD } & \multirow[b]{3}{*}{ SDconc $^{4}$} & \multicolumn{3}{|c|}{ Effects $^{2}$} \\
\hline & & & & & & & & & & & $\overline{\mathrm{DCAD}}$ \\
\hline & $\overline{\mathrm{LCLD}}$ & LCMD & LCHD & HCLD & HCMD & $\overline{\mathrm{HCHD}}$ & & & Conc & DCAD & $\times$ Conc \\
\hline \multicolumn{12}{|c|}{ Before the first meal at $0730 \mathrm{~h}$} \\
\hline $\mathrm{pH}$ & 7.49 & 7.50 & 7.50 & 7.49 & 7.49 & 7.53 & 0.036 & 0.026 & NS & $\mathrm{L}^{* *}$ & NS \\
\hline $\mathrm{pCO}_{2}, \mathrm{mmHg}$ & 38.9 & 39.3 & 40.1 & 38.1 & 41.0 & 38.6 & 3.74 & 2.75 & NS & $\mathrm{Q}^{\dagger}$ & $\mathrm{Q}^{*}$ \\
\hline $\mathrm{HCO}_{3}, \mathrm{mmol} / \mathrm{L}$ & 29.9 & 30.8 & 31.4 & 29.1 & 31.2 & 32.1 & 1.87 & 1.90 & NS & $\mathrm{L}^{* * * *}$ & $\mathrm{~L}^{\dagger}$ \\
\hline $\mathrm{SBE}, \mathrm{mmol} / \mathrm{L}$ & 6.09 & 7.02 & 7.55 & 5.39 & 7.23 & 8.42 & 1.850 & 1.852 & NS & $\mathrm{L}^{* * *}$ & $\mathrm{~L} \dagger$ \\
\hline $\mathrm{pH}$ & 7.47 & 7.47 & 7.48 & 7.45 & 7.48 & 7.49 & 0.037 & 0.026 & NS & $\mathrm{L}^{* *}$ & NS \\
\hline $\mathrm{pCO}_{2}, \mathrm{mmHg}$ & 39.3 & 39.9 & 40.0 & 39.5 & 38.8 & 38.5 & 3.29 & 2.70 & NS & NS & NS \\
\hline $\mathrm{HCO}_{3}, \mathrm{mmol} / \mathrm{L}$ & 28.1 & 28.6 & 29.7 & 27.3 & 27.9 & 29.1 & 2.03 & 1.47 & NS & $\mathrm{L}^{* * *}$ & NS \\
\hline $\mathrm{SBE}, \mathrm{mmol} / \mathrm{L}$ & 4.14 & 4.69 & 5.86 & 3.33 & 4.52 & 5.34 & 1.863 & 1.380 & NS & $\mathrm{L}^{* * *}$ & NS \\
\hline $\mathrm{Hb}, \mathrm{g} / 100 \mathrm{~mL}$ & 11.6 & 11.5 & 11.9 & 11.8 & 12.1 & 12.0 & 0.94 & 1.15 & NS & NS & NS \\
\hline
\end{tabular}

${ }^{1} \mathrm{LCLD}=$ Low concentrate and low DCAD; LCMD = low concentrate and medium DCAD; LCHD = low concentrate and high DCAD; $\mathrm{HCLD}=$ high concentrate and low DCAD; HCMD = high concentrate and medium DCAD; HCHD = high concentrate and high DCAD; DCAD expressed as $\mathrm{mEq} / \mathrm{kg}$ of $\mathrm{DM}(\mathrm{Na}+\mathrm{K})-(\mathrm{Cl}+\mathrm{S})$.

${ }^{2}$ Conc $=$ Concentration; $\mathrm{L}=$ linear effect; $\mathrm{Q}=$ quadratic effect.

${ }^{3} \mathrm{pCO}_{2}=$ blood $\mathrm{CO}_{2}$ partial pressure; $\mathrm{SBE}=$ standard base excess $; \mathrm{Hb}=$ hemoglobin.

${ }^{4}$ SDconc $=$ Standard deviation to test the concentrate effect.

$\dagger P \leq 0.10 ; * P \leq 0.05 ; * * P \leq 0.01 ; * * * P \leq 0.001 ; \mathrm{NS}=$ Nonsignificant.

by the level of concentrate either before the meal or at $1330 \mathrm{~h}$ (Table 2). Increasing DCAD produced a linear increase in blood $\mathrm{pH}$ as well as $\mathrm{HCO}_{3}$ and SBE concentrations both before the meal and at $1330 \mathrm{~h}$. The interaction between DCAD and level of concentrate was not significant. However, before the meal, the increase of blood $\mathrm{HCO}_{3}$ concentration and blood SBE with increasing DCAD tended to be greater at high than at low levels of concentrate $(P<0.10)$. Increasing DCAD only marginally affected $\mathrm{pCO}_{2}$ and hemoglobin concentration. Before the meal, $\mathrm{pCO}_{2}$ reached a higher value with the HCMD diet (41 $\mathrm{mmHg}$ ).

\section{Intake, Milk Production, Energy, and Protein Balances}

The DMI was not affected by concentrate level $(P>$ 0.10 , Table 3). However, concentrate supplementation modified the intake of starch, $\mathrm{NDF}, \mathrm{ADF}, \mathrm{NE}_{\mathrm{L}}, \mathrm{Na}, \mathrm{K}$, $\mathrm{Cl}$, and $\mathrm{S}$. In particular, starch intake increased from 6.68 to $8.60 \mathrm{~kg} / \mathrm{d}(P<0.001)$, whereas NDF intake dropped from 7.92 to $7.38 \mathrm{~kg} / \mathrm{d}$ between LC and HC diets $(P<0.05)$. Although the $\mathrm{NE}_{\mathrm{L}}$ intake was slightly increased $(P<0.10)$, the intake of PDI was unaffected. The high level of concentrate in the diets also resulted in increased intake of $\mathrm{Na}, \mathrm{K}(P<0.05), \mathrm{Cl}(P<0.01)$, and $\mathrm{S}(P<0.001)$. The effect of DCAD on DMI differed according to the level of concentrate (interaction of DCAD with level of concentrate, $P<0.01$ ). Increasing DCAD led to a linear increase of DMI with HC diets, but had no effect on intake with LC diets. Finally, DMI was similar for the $3 \mathrm{LC}$ diets and the HCLD diet (22.5 $\mathrm{kg} / \mathrm{d}$ on average), and rose by $1.5 \mathrm{~kg} / \mathrm{d}$ with the HCHD diet. Similar effects of DCAD were observed according to the level of concentrate for $\mathrm{NE}_{\mathrm{L}}$, protein, starch, and fiber intakes.

Milk yield was similar in all treatments (Table 4). When cows were fed the HC diets, milk fat percentage and yield decreased $(P<0.01)$, with $4 \%$ FCM yield following a similar trend $(P<0.10)$, whereas milk protein percentage and yield increased $(P<0.05)$. Increasing the DCAD level produced a linear increase in milk fat percentage, $4 \%$ FCM yield, and fat yield, but only with the HC diet. The interaction of DCAD with level of concentrate was highly significant $(P<0.01)$. Milk protein percentage and yield were not affected by DCAD variation $(P>0.10)$. Lactose concentration decreased with increasing level of concentrate $(P<0.05)$ but was unaffected by DCAD.

The energy balance was increased $(P<0.05)$ by increasing the level of concentrate, whereas the protein balance was unaffected. Both energy and protein balances were increased by increasing DCAD with the HC diets, but were unaffected with LC diets. Finally, the highest energy balance was obtained for the HCMD diet. Protein balance was lowest for the HCLD diet, whereas the HCMD and HCHD diets had similar values to those obtained with $\mathrm{LC}$ diets. The BW was not affected by the treatments.

\section{Milk Fatty Acid Composition and Yield}

Milk fatty acid composition and yield for the 12 selected cows are presented in Table 5. When cows were 
Table 3. Effects of DCAD and concentrate level on nutrient intake and BW

\begin{tabular}{|c|c|c|c|c|c|c|c|c|c|c|c|}
\hline & \multirow{2}{*}{\multicolumn{6}{|c|}{ Treatment $^{1}$}} & \multirow[b]{3}{*}{ SD } & \multirow[b]{3}{*}{ CDconc $^{3}$} & \multicolumn{3}{|c|}{ Effects $^{2}$} \\
\hline & & & & & & & & & & & DCAD \\
\hline & LCLD & LCMD & MCHD & HCLD & HCMD & $\mathrm{HCHD}$ & & & Conc & DCAD & $\times$ Conc. \\
\hline $\mathrm{DM}, \mathrm{kg}$ & 22.2 & 22.1 & 22.2 & 22.8 & 23.7 & 24.0 & 0.99 & 2.76 & NS & $\mathrm{L}^{* *}$ & $\mathrm{~L}^{* *}$ \\
\hline $\mathrm{NE}_{\mathrm{L}}$, Mcal & 34.9 & 34.9 & 34.8 & 36.1 & 37.6 & 37.9 & 1.550 & 4.364 & $\dagger$ & $\mathrm{L}^{*}$ & $\mathrm{~L}^{* *}$ \\
\hline $\mathrm{CP}, \mathrm{kg}$ & 3.23 & 3.20 & 3.19 & 3.26 & 3.35 & 3.39 & 0.146 & 0.403 & NS & NS & $\mathrm{L}^{* *}$ \\
\hline PDIE, $4 \mathrm{~kg}$ & 2.15 & 2.15 & 2.14 & 2.16 & 2.24 & 2.26 & 0.095 & 0.266 & NS & $\mathrm{L}^{*}$ & $\mathrm{~L}^{* *}$ \\
\hline $\mathrm{ADF}, \mathrm{kg}$ & 4.11 & 4.12 & 4.14 & 3.70 & 3.82 & 3.87 & 0.170 & 0.473 & $*$ & $\mathrm{~L}^{* *}$ & $\mathrm{~L} \dagger$ \\
\hline Starch, kg & 6.68 & 6.66 & 6.70 & 8.35 & 8.66 & 8.80 & 0.330 & 0.944 & $* * *$ & $\mathrm{~L}^{* *}$ & $\mathrm{~L}^{* *}$ \\
\hline $\mathrm{Na}, \mathrm{g}$ & 45.3 & 45.2 & 110.0 & 48.9 & 50.6 & 120.1 & 5.33 & 8.18 & $*$ & $\mathrm{~L}^{* * *}, \mathrm{Q}^{* * *}$ & $\mathrm{~L}^{* *}$ \\
\hline $\mathrm{K}, \mathrm{g}$ & 251.3 & 251.4 & 250.3 & 266.2 & 276.9 & 279.0 & 11.32 & 31.95 & $*$ & $\mathrm{~L}^{*}$ & $\mathrm{~L}^{* *}$ \\
\hline $\mathrm{Cl}, \mathrm{g}$ & 227.4 & 113.7 & 90.3 & 243.1 & 132.7 & 112.6 & 14.64 & 20.79 & $* *$ & $\mathrm{~L}^{* * *}, \mathrm{Q}^{* * *}$ & NS \\
\hline $\mathrm{S}, \mathrm{g}$ & 24.3 & 24.3 & 23.0 & 28.4 & 29.4 & 28.5 & 1.15 & 3.28 & $* * *$ & $\mathrm{~L}^{*}, \mathrm{Q}^{* * *}$ & $\mathrm{~L}^{* *}$ \\
\hline BW, kg & 636 & 638 & 638 & 643 & 645 & 640 & 10.8 & 63.9 & NS & NS & NS \\
\hline
\end{tabular}

${ }^{1} \mathrm{LCLD}=$ Low concentrate and low DCAD; LCMD = low concentrate and medium DCAD; LCHD = low concentrate and high DCAD; HCLD = high concentrate and low DCAD; HCMD = high concentrate and medium DCAD; HCHD = high concentrate and high DCAD; DCAD expressed as $\mathrm{mEq} / \mathrm{kg}$ of $\mathrm{DM}(\mathrm{Na}+\mathrm{K})-(\mathrm{Cl}+\mathrm{S})$.

${ }^{2}$ Conc $=$ Concentration; $\mathrm{L}=$ linear effect; $\mathrm{Q}=$ quadratic effect.

${ }^{3}$ SDconc $=$ Standard deviation to test the concentrate effect.

${ }^{4} \mathrm{PDIE}=$ Digestible protein in the small intestine supplied by microbial protein from rumen-fermented OM (Institut National de la Recherche Agronomique, 1989).

${ }^{5}$ PDIN = Digestible protein in the small intestine supplied by microbial protein from rumen-degraded protein (Institut National de la Recherche Agronomique, 1989).

$\dagger P \leq 0.10 ; * P \leq 0.05 ; * * P \leq 0.01 ; * * * P \leq 0.001 ; \mathrm{NS}=$ Nonsignificant.

fed the HC diets, the proportion of saturated odd-chain fatty acids in the milk increased $(P<0.01)$, whereas the proportion of even short-chain fatty acids $\left(\mathrm{C}_{4: 0}\right.$ to $\mathrm{C}_{12: 0}$ ) and the proportion of $\mathrm{C}_{16: 0}$ were unaffected by the level of concentrate. The proportion of $\mathrm{C}_{14: 0}(P<0.10)$ and $\mathrm{C}_{18: 0}(P<0.05)$ decreased with the HC diets. The proportion of monounsaturated fatty acids and, in particular, the proportion of $c i s-9 \mathrm{C}_{18: 1}$, trans- $10 \mathrm{C}_{18: 1}$, and trans-11 $\mathrm{C}_{18: 1}$ were not affected by the level of concentrate. The proportion of polyunsaturated fatty acids

Table 4. Effects of DCAD and concentrate level on milk yield, milk composition, and balances of energy and protein

\begin{tabular}{|c|c|c|c|c|c|c|c|c|c|c|c|}
\hline & \multirow{2}{*}{\multicolumn{6}{|c|}{ Treatment $^{1}$}} & \multirow[b]{3}{*}{ SD } & \multirow[b]{3}{*}{ SDconc $^{3}$} & \multicolumn{3}{|c|}{ Effects $^{2}$} \\
\hline & & & & & & & & & & & DCAD \\
\hline & LCLD & LCMD & LCHD & HCLD & HCMD & HCHD & & & Conc & DCAD & $\times$ Conc \\
\hline Milk & 28.3 & 28.5 & 28.8 & 29.2 & 29.3 & 29.3 & 1.36 & 4.36 & NS & NS & NS \\
\hline $4 \% \mathrm{FCM}$ & 28.9 & 29.1 & 29.4 & 26.4 & 27.0 & 28.2 & 1.37 & 3.95 & $\dagger$ & $\mathrm{L}^{* * *}$ & $\mathrm{~L}^{*}$ \\
\hline Fat & 1.17 & 1.18 & 1.19 & 0.98 & 1.02 & 1.10 & 0.070 & 0.148 & $* *$ & $\mathrm{~L}^{* * *}$ & $\mathrm{~L}^{* *}$ \\
\hline Protein & 0.91 & 0.90 & 0.91 & 0.97 & 0.97 & 0.98 & 0.043 & 0.101 & $*$ & NS & NS \\
\hline Protein & 3.22 & 3.18 & 3.18 & 3.35 & 3.35 & 3.36 & 0.070 & 0.247 & $*$ & NS & NS \\
\hline Lactose, g/L & 48.8 & 49.2 & 48.9 & 46.8 & 47.3 & 46.8 & 0.68 & 1.93 & $*$ & NS & NS \\
\hline \multicolumn{12}{|l|}{ Balances } \\
\hline Energy, Mcal/d & 3.08 & 2.98 & 2.62 & 4.74 & 5.70 & 5.17 & 1.109 & 3.365 & $*$ & $\mathrm{Q}^{*}$ & $\mathrm{~L} \dagger$ \\
\hline Protein, g of $\mathrm{PDI}^{4} / \mathrm{d}$ & 291 & 278 & 257 & 173 & 231 & 250 & 80.9 & 239.0 & NS & NS & $\mathrm{L}^{* *}$ \\
\hline
\end{tabular}

${ }^{1} \mathrm{LCLD}=$ Low concentrate and low DCAD; LCMD = low concentrate and medium DCAD; LCHD = low concentrate and high DCAD; HCLD = high concentrate and low DCAD; HCMD = high concentrate and medium DCAD; HCHD = high concentrate and high DCAD; DCAD expressed as $\mathrm{mEq} / \mathrm{kg}$ of $\mathrm{DM}(\mathrm{Na}+\mathrm{K})-(\mathrm{Cl}+\mathrm{S})$.

${ }^{2}$ Conc $=$ Concentration; $\mathrm{L}=$ linear effect; $\mathrm{Q}=$ quadratic effect.

${ }^{3}$ SDconc $=$ Standard deviation to test the concentrate effect.

${ }^{4} \mathrm{PDI}=$ Digestible protein in the small intestine (Institut National de la Recherche Agronomique, 1989).

$\dagger P \leq 0.10 ; * P \leq 0.05 ; * * P \leq 0.01 ; * * * P \leq 0.001$; NS = Nonsignificant. 
Table 5. Effects of DCAD and concentrate level on milk fatty acid composition (g/100 g) and production (g/d)

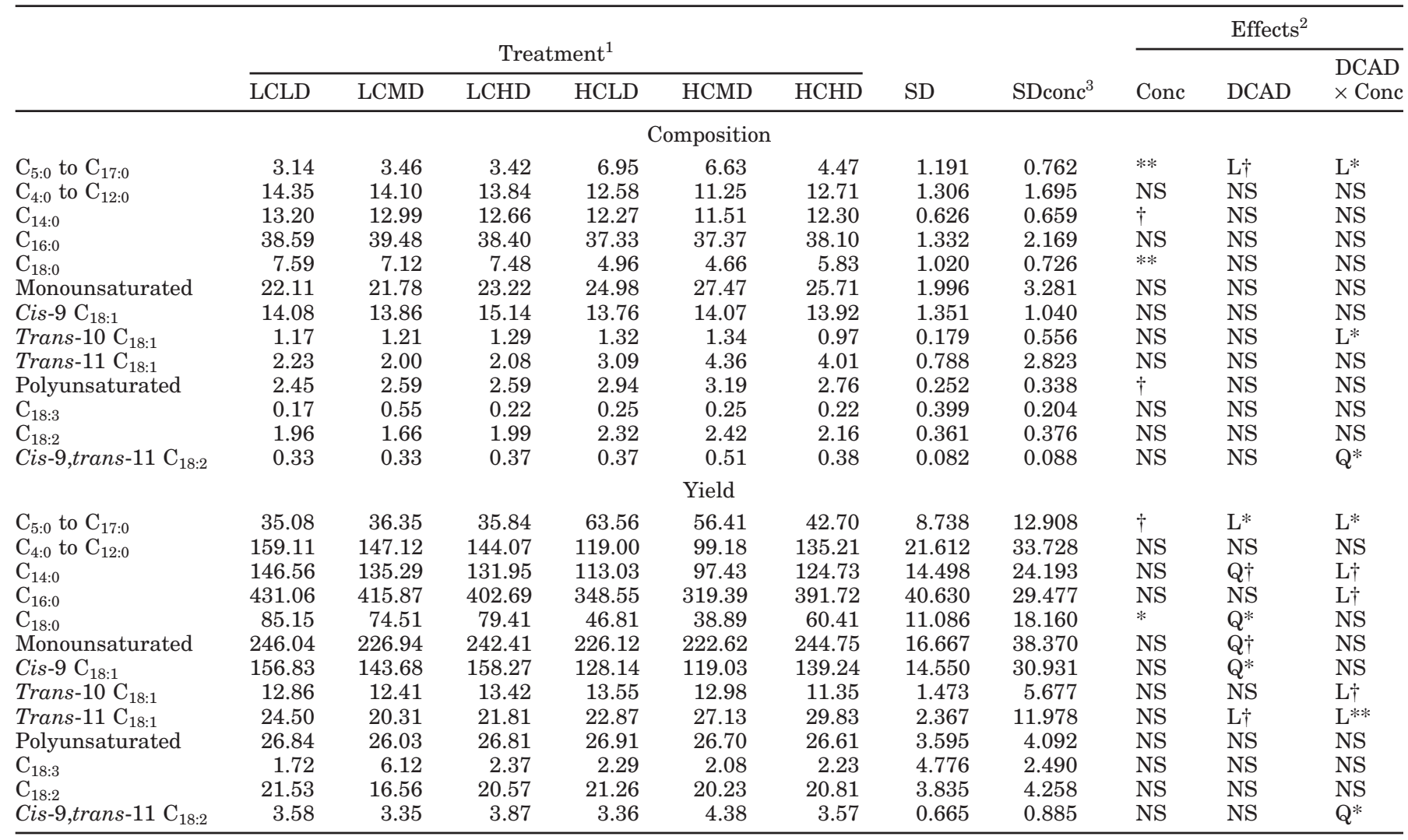

${ }^{1} \mathrm{LCLD}=$ Low concentrate and low DCAD; LCMD = low concentrate and medium DCAD; LCHD = low concentrate and high DCAD; HCLD = high concentrate and low DCAD; HCMD = high concentrate and medium DCAD; HCHD = high concentrate and high DCAD; DCAD expressed as $\mathrm{mEq} / \mathrm{kg}$ of $\mathrm{DM}(\mathrm{Na}+\mathrm{K})-(\mathrm{Cl}+\mathrm{S})$.

${ }^{2}$ Conc $=$ Concentration; $\mathrm{L}=$ linear effect; $\mathrm{Q}=$ quadratic effect.

${ }^{3}$ SDconc $=$ Standard deviation to test the concentrate effect.

$\dagger P \leq 0.10 ; * P \leq 0.05 ; * * P \leq 0.01 ; \mathrm{NS}=$ Nonsignificant.

tended to increase with the increase in concentrate, whereas the proportions of $\mathrm{C}_{18: 3}, \mathrm{C}_{18: 2}$, and cis-9,trans$11 \mathrm{C}_{18: 2}$ were unaffected. Increasing DCAD tended to decrease the proportion of odd-chain fatty acids, especially with the HC diet (interaction of DCAD with level of concentrate, $P<0.05$ ). The proportions of short and medium fatty acids, as well as the proportions of monoand polyunsaturated fatty acids, were unaffected by altering DCAD. This did not apply to the proportion of trans-10 $\mathrm{C}_{18: 1}$, which showed a decrease with increasing $\mathrm{DCAD}$ only when cows were fed the $\mathrm{HC}$ diet (interaction of DCAD with level of concentrate, $P<0.05$ ).

The yield of all saturated odd-chain fatty acids $\left(\mathrm{C}_{5: 0}\right.$ to $\left.\mathrm{C}_{17: 0}\right)$ was increased $(P=0.07)$ when cows were fed the $\mathrm{HC}$ diets. The yield of even short-chain fatty acids $\left(\mathrm{C}_{4: 0}\right.$ to $\left.\mathrm{C}_{12: 0}\right)$ and medium fatty acids $\left(\mathrm{C}_{14: 0}\right.$ and $\left.\mathrm{C}_{16: 0}\right)$ was unaffected by the level of concentrate, whereas the yield of $\mathrm{C}_{18: 0}$ showed a decrease $(P<0.05)$. The yield of mono- and polyunsaturated fatty acids was unaffected with $\mathrm{HC}$ diets. The effect of DCAD on the yield of satu- rated odd-chain fatty acid differed according to the level of concentrate (interaction of DCAD with level of concentrate, $P<0.05$ ). The yield of all these fatty acids decreased linearly $(P<0.05)$ with increasing DCAD when $\mathrm{HC}$ diets were fed, but remained unaffected when LC diets were fed. The yield of saturated odd-chain fatty acids averaged $35.8 \mathrm{~g} / \mathrm{d}$ with LC diets and fell from 63.6 to $42.7 \mathrm{~g} / \mathrm{d}$ with increasing DCAD with $\mathrm{HC}$ diets. The yield of even short-chain fatty acids $\left(\mathrm{C}_{4: 0}\right.$ to $\mathrm{C}_{12: 0}$ ) was not affected by DCAD level. The yield of $\mathrm{C}_{16: 0}$ tended to increase with increasing DCAD, but only with the HC diet (interaction of DCAD with level of concentrate, $P=0.09$ ). Although increasing DCAD decreased the yield of trans-10 $\mathrm{C}_{18: 1}$ and increased the yield of trans-11 $\mathrm{C}_{18: 1}$ with $\mathrm{HC}$ diets, it did not affect the yield of these fatty acids on LC diets (interaction of DCAD with level of concentrate, $P=0.08$ and $P<0.05$ with $\mathrm{HC}$ and LC, respectively). The yield of polyunsaturated fatty acids was not affected by DCAD. The yields of $\mathrm{C}_{18: 0}$, cis-9 $\mathrm{C}_{18: 1}$, and $\mathrm{C}_{14: 0}$ were hardly affected, except 
Table 6. Effects of DCAD and concentrate level on blood minerals (expressed as mEq/L)

\begin{tabular}{|c|c|c|c|c|c|c|c|c|c|c|c|}
\hline & \multirow{2}{*}{\multicolumn{6}{|c|}{ Treatment $^{1}$}} & \multirow[b]{3}{*}{ SD } & \multirow[b]{3}{*}{ SDconc $^{3}$} & \multicolumn{3}{|c|}{ Effects $^{2}$} \\
\hline & & & & & & & & & & & DCAD \\
\hline & LCLD & LCMD & LCHD & HCLD & HCMD & $\mathrm{HCHD}$ & & & Conc & DCAD & $\times$ Conc \\
\hline \multicolumn{12}{|c|}{ Before the first meal at $0730 \mathrm{~h}$} \\
\hline $\mathrm{Na}$ & 136 & 137 & 136 & 136 & 136 & 136 & 1.9 & 1.2 & $\dagger$ & NS & NS \\
\hline $\mathrm{K}$ & 4.26 & 4.34 & 4.16 & 6.12 & 4.27 & 4.45 & 3.465 & 1.956 & NS & NS & NS \\
\hline $\mathrm{Cl}$ & 93.6 & 92.7 & 91.8 & 94.4 & 92.9 & 91.6 & 2.0 & 1.6 & NS & $\mathrm{L}^{* * *}$ & NS \\
\hline \multirow{2}{*}{$\begin{array}{l}\mathrm{Ca} \\
\mathrm{ED}^{4}\end{array}$} & 2.42 & 2.46 & 2.40 & 2.42 & 2.41 & 2.34 & 0.152 & 0.087 & NS & NS & NS \\
\hline & 46.8 & 48.3 & 48.8 & 47.4 & 47.6 & 48.5 & 3.95 & 2.28 & NS & NS & NS \\
\hline \multicolumn{12}{|c|}{ At $1330 \mathrm{~h}$} \\
\hline $\mathrm{Na}$ & 138 & 137 & 138 & 139 & 138 & 139 & 1.8 & 1.1 & $*$ & NS & NS \\
\hline $\mathrm{K}$ & 4.15 & 4.11 & 4.08 & 4.18 & 3.91 & 4.02 & 0.232 & 0.212 & NS & $L^{*}, Q^{*}$ & $\mathrm{~L}^{*}$ \\
\hline $\mathrm{Cl}$ & 94.7 & 93.5 & 93.0 & 96.0 & 94.5 & 93.9 & 2.23 & 1.41 & $*$ & $\mathrm{~L}^{* * *}$ & NS \\
\hline $\mathrm{Ca}$ & 2.48 & 2.48 & 2.44 & 2.46 & 2.43 & 2.38 & 0.146 & 0.092 & NS & $\mathrm{L} \dagger$ & NS \\
\hline $\mathrm{ED}^{4}$ & 47.3 & 48.0 & 49.0 & 44.8 & 45.4 & 46.8 & 1.54 & 4.64 & $\dagger$ & $\mathrm{L}^{* * *}$ & NS \\
\hline $\begin{array}{r}{ }^{1} \mathrm{LC} \\
\text { conce } \\
\text { medi } \\
-(\mathrm{Cl} \\
{ }^{2} \mathrm{Cc} \\
{ }^{3} \mathrm{SI} \\
{ }^{4} \mathrm{EI} \\
{ }_{\dagger} \mathrm{P}\end{array}$ & $\begin{array}{l}\text { S). } \\
c=\text { Con } \\
\text { onc }=\mathrm{S} \\
=\text { Electr } \\
0.10 ; * I\end{array}$ & $\begin{array}{l}\text { v concent } \\
\text { d high D } \\
\text {; HCHD } \\
\text { entration } \\
\text { andard d } \\
\text { olyte diff } \\
\leq 0.05 \text {; }\end{array}$ & $\begin{array}{l}\text { rate and } \\
\text { CAD; HC } \\
=\text { high cc } \\
\\
\text {; L = lin } \\
\text { eviation } \\
\text { rence; e }\end{array}$ & $\begin{array}{l}\text { ow DCA } \\
\mathrm{D}=\mathrm{hi} \\
\text { centrat } \\
\text { r effect } \\
\text { test th } \\
\text { ressed }\end{array}$ & $\begin{array}{l}\mathrm{D} \text {; LCML } \\
\text { h concen } \\
\text { and high } \\
\mathrm{Q}=\text { qua } \\
\text { concents } \\
\text { s } \mathrm{mEq} / \mathrm{L}\end{array}$ & $\begin{array}{l}=\text { low co } \\
\text { cate and } \\
\text { DCAD; } \\
\text { ratic effe } \\
\text { ate effect } \\
\mathrm{Na}+\mathrm{K} \text { ) }\end{array}$ & $\begin{array}{l}\text { acent } \\
\text { low I } \\
\text { CAD } \\
\text { - Cl. }\end{array}$ & $\begin{array}{l}\text { and } \mathrm{m} \\
\text {; } \mathrm{HC} \\
\text { essed }\end{array}$ & $\begin{array}{l}\mathrm{um}_{=\mathrm{h}} \\
\mathrm{mEg}\end{array}$ & $\begin{array}{l}\mathrm{D} ; \mathrm{LC} \\
\text { concer } \\
\text { of } \mathrm{DM}\end{array}$ & $\begin{array}{l}=\text { low } \\
\text { te and } \\
(a+K)\end{array}$ \\
\hline
\end{tabular}

in the case of the HCMD diet when their yield was low. Indeed, when fed the HCMD diet, the cows chosen for fatty acid analysis produced less milk fat than all of the experimental cows $(0.98$ vs. $1.19 \mathrm{~kg} / \mathrm{d})$.

\section{Blood and Milk Minerals}

Blood mineral concentrations varied little with the treatments (Table 6). Before the meal, blood mineral concentrations were unaffected by the treatments, except for the concentration of $\mathrm{Cl}$, which decreased linearly with falling $\mathrm{Cl}$ input $(P<0.001)$. At $1330 \mathrm{~h}$, blood $\mathrm{Na}$ and $\mathrm{Cl}$ concentrations showed an increase $(P<0.05)$ when $\mathrm{HC}$ diets were fed. Blood $\mathrm{Cl}(P<0.001)$ and $\mathrm{Ca}$ $(P<0.10)$ concentrations decreased with falling $\mathrm{Cl}$ input and $\mathrm{K}$ concentration was minimal when HCMD diet was fed. Finally, the blood electrolyte difference (expressed as $\mathrm{mEq} / \mathrm{L}$ of $\mathrm{Na}+\mathrm{K}-\mathrm{Cl}$ ) was not affected by the treatments before the meal, but increased $(P<$ 0.001 ) with increasing DCAD, and tended to be lower for HC than for LC diets $(P<0.10)$ at $1330 \mathrm{~h}$.

Milk $\mathrm{pH}$ was unaffected by treatments and averaged 6.66 (Table 7). Milk mineral concentrations varied slightly with the treatments, except for $\mathrm{Cl}$, which was markedly higher with the HC than with the LC diets, and decreased linearly with increasing DCAD. The K concentration increased when $\mathrm{HC}$ diets were fed but did not vary as a function of DCAD. The Na concentration in milk tended to decrease with increasing DCAD or when HC diets were fed.

\section{Metabolic Parameters}

Increasing the proportion of concentrate decreased blood BHBA $(P<0.001)$ and increased plasma glucose concentration $(P<0.05)$, but did not affect plasma NEFA, lactate, and urea concentrations (Table 8). The plasma concentrations of NEFA and BHBA increased as a function of DCAD when cows were fed the high level of concentrate but remained unaffected when cows were fed the low level of concentrates. Finally, plasma NEFA and BHBA concentrations were at a minimum when cows were fed the HCLD diet. Increasing DCAD did not affect the glucose concentration. Although urea level showed no variation between low and medium DCAD, it slightly decreased between medium and high DCAD. Lactate concentration was unaffected by DCAD level.

\section{DISCUSSION}

\section{Effect of Concentrate on Cow Responses}

The increase in the proportion of concentrate was designed to create 2 contrasting ruminal conditions, while maintaining a fiber level in the $\mathrm{HC}$ diets close to the commonly accepted minimum limit for preventing 
Table 7. Effects of DCAD and concentrate level on milk $\mathrm{pH}$ and minerals (expressed as $\mathrm{mEq} / \mathrm{L}$ )

\begin{tabular}{|c|c|c|c|c|c|c|c|c|c|c|c|}
\hline & \multirow{2}{*}{\multicolumn{6}{|c|}{ Treatment $^{1}$}} & \multirow[b]{3}{*}{ CD } & \multirow[b]{3}{*}{ SDconc $^{3}$} & \multicolumn{3}{|c|}{ Effects $^{2}$} \\
\hline & & & & & & & & & & & $\overline{\mathrm{DCAD}}$ \\
\hline & $\overline{\mathrm{LCLD}}$ & LCMD & LCHD & HCLD & HCMD & $\overline{\mathrm{HCHD}}$ & & & Conc & DCAD & $\times$ Conc \\
\hline $\mathrm{pH}$ & 6.66 & 6.68 & 6.69 & 6.55 & 6.57 & 5.80 & 0.824 & 0.416 & NS & NS & NS \\
\hline $\mathrm{Na}$ & 14.2 & 15.2 & 14.6 & 16.3 & 15.7 & 15.0 & 0.42 & 1.87 & NS & $\mathrm{L} \dagger, \mathrm{Q}^{*}$ & $\mathrm{~L}^{* *}, \mathrm{Q} \dagger$ \\
\hline $\mathrm{K}$ & 41.8 & 42.8 & 42.0 & 46.6 & 45.4 & 44.4 & 1.97 & 0.65 & $* * *$ & NS & NS \\
\hline $\mathrm{Cl}$ & 24.2 & 23.6 & 21.3 & 33.0 & 32.2 & 29.9 & 2.55 & 3.97 & $*$ & $\mathrm{~L}^{*}$ & NS \\
\hline $\mathrm{ED}^{4}$ & 31.8 & 34.3 & 35.3 & 29.9 & 28.9 & 29.5 & 3.32 & 3.36 & $\dagger$ & NS & NS \\
\hline
\end{tabular}

${ }^{1}$ LCLD = Low concentrate and low DCAD; LCMD = low concentrate and medium DCAD; LCHD = low concentrate and high DCAD; HCLD = high concentrate and low DCAD; HCMD = high concentrate and medium DCAD; HCHD = high concentrate and high DCAD; DCAD expressed as $\mathrm{mEq} / \mathrm{kg}$ of $\mathrm{DM}(\mathrm{Na}+\mathrm{K})$ $-(\mathrm{Cl}+\mathrm{S})$

${ }^{2}$ Conc $=$ Concentration; $\mathrm{L}=$ linear effect; $\mathrm{Q}=$ quadratic effect.

${ }^{3} \mathrm{SDconc}=$ Standard deviation to test the concentrate effect.

${ }^{4} \mathrm{ED}=$ Electrolyte difference; expressed as $\mathrm{mEq} / \mathrm{L}(\mathrm{Na}+\mathrm{K})-\mathrm{Cl}$.

$\dagger P \leq 0.10 ; * P \leq 0.05 ; * * P \leq 0.01 ; * * * P \leq 0.001$; NS $=$ Nonsignificant.

pathological risks. The NDF from forage accounted for $22 \%$ of the diet DM and represented a daily intake equivalent to $0.8 \%$ of BW for HCLD diets. Although NDF from forage did not exactly correspond to the potentially effective NDF (peNDF) and effective NDF (eNDF) criteria, the observed values were rather low compared with the requirements proposed by Mertens (1997) to limit the risk of subacute rumen acidosis: peNDF higher than $24 \% \mathrm{DM}$ and eNDF higher than $0.9 \% \mathrm{BW}$.

Some of the animal responses indicate that 2 contrasting ruminal conditions were created. The milk fat content decreased from $4.23 \%$ during the pre-experimental period to $3.58 \%$ when cows were fed $\mathrm{HC}$ diets, even though the fatty acid composition of the diet was not modified. This decrease in milk fat percentage is typical of a modification of rumen fermentations related to concentrate-rich diets (Doreau et al., 1999). In an experiment with fistulated cows receiving the same diets, ruminal $\mathrm{pH}$ (6.06 vs. 6.33) and acetate:propionate ratio (2.36 vs. 2.83) were lower in HC than in LC cows (Apper-Bossard and Peyraud, 2004). The increased production of milk odd-chain fatty acids in HC cows may be related to increased production of propionate in the rumen, because the utilization of propionate is well known in the synthesis of odd-chain fatty acids in milk (Emmanuel and Kennelly, 1985). The higher concentration of glucose and lower concentration of BHBA in plasma of $\mathrm{HC}$ cows, together with the lower production of $\mathrm{C}_{18: 0}$ in milk, might reflect higher propionate production in the rumen leading to a more anabolic profile compared with LC cows. Finally, we did not observe any overall effect of concentrate level on DMI. Concentrate supplementation is expected to increase DMI and milk yield, the substitution between concentrate and forages being lower than 1.0 irrespective of the carbohydrate source (Faverdin et al., 1987). Peyraud (2000) reported a substitution rate higher than 1.0 when increasing the proportion of wheat from 20 to $36 \%$ in cows fed a finely

Table 8. Effects of DCAD and concentrate level on blood metabolism parameters before meal

\begin{tabular}{|c|c|c|c|c|c|c|c|c|c|c|c|}
\hline & \multirow{2}{*}{\multicolumn{6}{|c|}{ Treatment $^{1}$}} & \multirow[b]{3}{*}{ SD } & \multirow[b]{3}{*}{ SDconc $^{3}$} & \multicolumn{3}{|c|}{ Effects $^{2}$} \\
\hline & & & & & & & & & & & $\overline{\mathrm{DCAD}}$ \\
\hline & LCLD & LCMD & LCHD & HCLD & HCMD & $\mathrm{HCHD}$ & & & Conc & DCAD & $\times$ Conc \\
\hline $\mathrm{BHBA}, \mathrm{mmol} / \mathrm{L}$ & 0.61 & 0.65 & 0.59 & 0.36 & 0.41 & 0.51 & 0.123 & 0.131 & $* * *$ & $\mathrm{~L}^{*}$ & $\mathrm{~L}^{* *}, \mathrm{Q} \dagger$ \\
\hline Lactate, mmol/L & 0.31 & 0.29 & 0.36 & 0.32 & 0.32 & 0.37 & 0.204 & 0.170 & NS & NS & NS \\
\hline Glucose, mg/L & 710 & 696 & 712 & 730 & 732 & 720 & 29.9 & 29.2 & * & NS & $\mathrm{Q}^{*}$ \\
\hline Urea, mg/L & 254 & 268 & 242 & 247 & 256 & 226 & 37.3 & 41.1 & NS & $L^{*}, Q^{* *}$ & NS \\
\hline
\end{tabular}

${ }^{1} \mathrm{LCLD}=$ Low concentrate and low DCAD; LCMD = low concentrate and medium DCAD; LCHD = low concentrate and high DCAD; HCLD = high concentrate and low DCAD; HCMD = high concentrate and medium DCAD; HCHD = high concentrate and high DCAD; DCAD expressed as $\mathrm{mEq} / \mathrm{kg}$ of $\mathrm{DM}(\mathrm{Na}+\mathrm{K})-(\mathrm{Cl}+\mathrm{S})$.

${ }^{2}$ Conc $=$ Concentration; $\mathrm{L}=$ linear effect; $\mathrm{Q}=$ quadratic effect.

${ }^{3}$ SDconc $=$ Standard deviation to test the concentrate effect.

$\dagger P \leq 0.10 ; * P \leq 0.05 ; * * P \leq 0.01 ; * * * P \leq 0.001 ; \mathrm{NS}=$ Nonsignificant. 
ground diet, leading to very low ruminal $\mathrm{pH}$ after the meal (5.7) and a very low acetate:propionate ratio (1.9).

\section{Increase of DCAD Increases Intake and Milk Fat Content, but only in HC Cows}

Increasing DCAD produced a linear increase of DMI for HC-fed cows. Previous studies have also reported, for a similar range of variation of DCAD, a positive correlation between DCAD and DMI in lactating cows fed high-concentrate and low-roughage diets (Tucker et al., 1988; Waterman et al., 1991; West et al., 1992). On the contrary, our results show that increasing DCAD does not affect DMI in LC cows. Thus, it appears that high DCAD leads to an increase in DMI when concentrates rich in rapidly degradable starch make up a high proportion of the diet offered to dairy cows. For high DCAD, the effect of concentrate on DMI is within the range predicted by the French Fill Units $(+1.4 \mathrm{~kg}$ $\mathrm{DM} / \mathrm{d})$. On the other hand, for low DCAD, the concentrate failed to produce an increase in DMI. Roche et al. (2005) also reported a positive correlation between DCAD and DMI in dairy cows fed fresh forages. Fresh high-quality pastures lead to very low rumen $\mathrm{pH}$ (Delagarde et al., 1998), suggesting that altering DCAD could affect DMI not only with high-concentrate diets but also more generally for diets causing low ruminal $\mathrm{pH}$.

In $\mathrm{HC}$ cows, the increase in DCAD produces an increase in milk fat percentage and fat yield, resulting in an increase of $4 \% \mathrm{FCM}$ yield but no effect on milk yield. The increase in $4 \% \mathrm{FCM}$ by $1.8 \mathrm{~kg} / \mathrm{d}$ corresponds to an additional requirement of $1.36 \mathrm{MCal} / \mathrm{d}$ of net energy, which accounts for $75 \%$ of the additional supply of net energy intake. West et al. (1992) and Tucker et al. (1994) reported an increase in the milk fat percentage on increasing DCAD, without any effect on milk yield. In these studies, as in the present trial, cows fed with the low DCAD diet produced low fat milk (3.4\%), but the blood $\mathrm{pH}$ (7.45) and blood $\mathrm{HCO}_{3}$ concentration $(27 \mathrm{mEq} / \mathrm{L})$ suggests they were not under conditions of subacute metabolic acidosis (Schotman, 1971). Roche et al. (2005) reported similar results with cows fed fresh forages. Conversely, some studies have reported an increase in milk yield without changes in milk fat percentage (Tucker et al., 1991; West et al., 1991). In these studies, cows were in subacute metabolic acidosis, as indicated by low blood $\mathrm{pH}$ values (7.34) and blood $\mathrm{HCO}_{3}$ concentration $(19 \mathrm{mEq} / \mathrm{L})$. However, the cows produced milk with a normal fat percentage (ranging from 3.8 to $4.2 \%$ ), suggesting that they did not develop a subacute rumen acidosis. When subacute rumen and subacute metabolic acidosis were induced by feeding a very rich concentrate diet with negative DCAD, both the milk yield and the milk fat percentage rose as a function of increasing DCAD (Escobosa et al., 1984). These responses were related to large increases in DMI (6 kg/ d). Thus, it appears that increasing the DCAD produces an increase in milk fat content without any change in milk yield when cows are fed highly degradable diets but are not in metabolic acidosis.

Finally, although no specific DCAD level seems to be required when cows are fed slowly degradable diets, positive DCAD levels are required to maximize DMI and FCM when being fed highly degradable diets. Because the response curves in our study were linear, it was not possible to find a threshold value above which there was little or no effect of DCAD on DMI. However, we can recommend a DCAD level not exceeding 300 $\mathrm{mEq} / \mathrm{kg}$ of $\mathrm{DM}$ in view of the fact that several studies show DMI reaching a plateau, or even slightly decreasing, for DCAD values higher than $300 \mathrm{mEq} / \mathrm{kg} \mathrm{DM}(\mathrm{Hu}$ and Murphy, 2004).

\section{Mechanisms Contributing to the Increase of Intake and 4\% FCM Yield}

The increase of milk fat percentage with increasing DCAD only occurs when cows are fed high-concentrate diets. This suggests a rumen buffering effect of DCAD, partly supported by the change in milk fatty acids yield, because DCAD modifies the yield of several fatty acids in $\mathrm{HC}$ but not in LC cows.

Firstly, in $\mathrm{HC}$ cows, the yield of trans-10 $\mathrm{C}_{18: 1}$ shows a decrease with increasing $\mathrm{DCAD}$, whereas the yield of trans-11 $\mathrm{C}_{18: 1}$ increases sharply. These results are induced by changes in microbial processes involving a shift in the biohydrogenation pathways of $\mathrm{C}_{18: 2}$ that become oriented toward trans-11 $\mathrm{C}_{18: 1}$ rather than trans-10 $\mathrm{C}_{18: 1}$ (Bauman and Griinari, 2003). This shift might be due to a ruminal buffering effect of DCAD. Kalscheur et al. (1997) showed that trans-10 $\mathrm{C}_{18: 1}$ was produced when ruminal $\mathrm{pH}$ decreased. In an experiment with fistulated cows receiving the same $\mathrm{HC}$ diets, Apper-Bossard and Peyraud (2004) showed that high DCAD lowers the decrease in ruminal $\mathrm{pH}$ during the meal. Higher blood $\mathrm{HCO}_{3}$ concentration with high DCAD may increase $\mathrm{HCO}_{3}$ recycling into the rumen with the saliva, thus contributing to the possible ruminal buffering effect of high DCAD. Because the increased milk fat content of trans-10 $\mathrm{C}_{18: 1}$ is typical of diets causing milk fat depression (Griinari et al., 1999), these changes in ruminal metabolism may explain the positive correlation between DCAD and milk fat percentage in HC cows. Indeed, several studies have demonstrated that trans-10 cis-12 $\mathrm{C}_{18: 2}$ is an inhibitor of milk fat synthesis (Baumgard et al., 2001). Although this fatty acid was not determined in the present study, the trans- 10 cis- $12 \mathrm{C}_{18: 2}$ and trans- $10 \mathrm{C}_{18: 1}$ levels are 
closely correlated in milk fat (Loor and Herbein, 2001), suggesting that the yield of trans-10,cis-12 $\mathrm{C}_{18: 2}$ might be affected by DCAD.

Secondly, increasing DCAD causes a drop in the yield of odd-chain fatty acids in milk. Odd-chain fatty acids arise from propionate elongation and are of microbial origin. Therefore, despite the increase in DMI (and increase in production of VFA), a lower yield of these fatty acids may indicate a lower proportion of ruminal propionate or modifications of the microbial synthesis and flow into the duodenum. The possible higher production of propionate at low $\mathrm{DCAD}$ is also in agreement with the low blood NEFA concentration found when feeding HCLD because propionate is insulinotropic and favors $\mathrm{C}_{18: 0}$ use by adipose tissue (De Jong, 1982).

Besides the ruminal buffering effect of DCAD, we cannot rule out that an improvement in the cow's acidbase status could favor the response of DMI. The increase of DCAD led to an increase in blood $\mathrm{pH}$, blood $\mathrm{HCO}_{3}$ concentration, and SBE, in agreement with the data of $\mathrm{Hu}$ and Murphy (2004). In the present study, blood $\mathrm{pH}$, blood $\mathrm{HCO}_{3}$ concentration, and base excess are similar or higher with HCHD than with the $3 \mathrm{LC}$ diets in spite of large differences in DMI of rapidly degradable starch $(0.8 \mathrm{vs} .5 .4 \mathrm{~kg} / \mathrm{d}$ of the wheat-barley mixture). Thus, high DCAD might prevent any drop in blood acid-base status when feeding high amounts of rapidly degradable starch. Previous studies have shown a drop in blood $\mathrm{HCO}_{3}$ concentration and base excess when dairy cows or beef cattle were challenged with high amounts of starch (Goad et al., 1998; Faverdin et al., 1999) and this decrease was accompanied by a reduction in DMI.

\section{CONCLUSIONS}

The results of this study clearly show the role of DCAD in regulating DMI, milk fat yield, and blood acidbase status. However, the responses vary according to other characteristics of the diet. Increasing DCAD improves the cow's performance when fed highly degradable diets, or more generally when receiving diets causing low rumen $\mathrm{pH}$. We can recommend an input of 150 to $300 \mathrm{mEq} / \mathrm{kg}$ of $\mathrm{DM}$ to these diets.

\section{ACKNOWLEDGMENTS}

The authors gratefully acknowledge the INZO and IN VIVO groups for their financial support. They are especially grateful to the farm staff of Mejusseaume for cow welfare, feeding, and sampling. The authors also thank the technician staff of St Gilles and the IN VIVO group for their assistance in analysis. The authors thank M. S. N. Carpenter for editing the manuscript for English style.

\section{REFERENCES}

AOAC. 1984. Official Methods of Analysis. 14th ed. Association of Official Analytical Chemists, Arlington, VA.

Apper-Bossard, E., and J. L. Peyraud. 2004. Dietary cation-anion difference could enhance acid-base status of lactating dairy cows submitted to a subacidosis. The 10th Int. Symp. Ruminant Physiology, Copenhagen, Denmark. J. Anim. Feed Sci. 13(Suppl. 1):27-30.

Association Française de Normalisation. 1985a. Aliments des animaux. Dosage de l'azote en vue de calcul de la teneur en protéines brutes. Pages 87-93 in Association Française de Normalisation, Paris, France.

Association Française de Normalisation. 1985b. Aliments des animaux. Dosage de l'amidon. Méthode polarimétrique. Pages 123125 in Association Française de Normalisation, Paris, France.

Bauchart, D., and F. Duboisset. 1983. Utilisation des colonnes capillaires de verre pour l'analyse des acides gras du lait. Cah. Techn. INRA 1:37-46.

Bauman, D. E., and J. M. Griinari. 2003. Nutritional regulation of milk fat synthesis. Annu. Rev. Nutr. 23:203-227.

Baumgard, L. H., J. K. Sangster, and D. E. Bauman. 2001. Milk fat synthesis in dairy cows is progressively reduced by increasing supplemental amounts of trans-10,cis-12 conjugated linoleic acid (CLA). J. Nutr. 131:1764-1769.

De Jong, A. 1982. Patterns of plasma concentrations of insulin and glucagon after intravascular and intraruminal administration of volatile fatty acids in the goat. J. Endocrinol. 92:357-370.

Delagarde, R., J. L. Peyraud, and L. Delaby. 1998. Influence of carbohydrate or protein supplementation on intake, behaviour and digestion in dairy cows strip-grazing low-nitrogen fertilized perennial ryegrass. Ann. Zootec. 48:81-96.

Doreau, M., Y. Chilliard, H. Rulquin, and P. Demeyer. 1999. Manipulation of milk fat in dairy cows. Pages 81-109 in Recent Advances in Animal Nutrition. P. C. Garnsworthy, J. Wiseman, ed. Nottingham University Press, Nottingham, UK.

Emmanuel, B., and J. J. Kennelly. 1985. Measures of de novo synthesis of milk components from propionate in lactating goats. J. Dairy Sci. 68:312-319.

Escobosa, A., C. E. Coppock, L. D. Rowe, Jr., W. L. Jenkins, and C. E. Gates. 1984. Effects of dietary sodium bicarbonate and calcium chloride on physiological responses of lactating dairy cows in hot weather. J. Dairy Sci. 67:574-584.

Faverdin, P., N. Bareille, and R. Vérité. 1999. Effects of rumen energy supply timing on feed intake control in lactating dairy cows. J. Dairy Sci. 82:2443-2454.

Faverdin, P., A. Hoden, and J. B. Coulon. 1987. Recommandations alimentaires pour les vaches laitières. Bull. Techn. CRZV Theix 70:133-152.

Gill, J. L. 1978. Completely randomized designs of analysis of variance. Pages 135-258 in Design and Analysis of Experiments in the Animal and Medical Sciences. Vol. 1. Iowa State Univ. Press, Ames.

Goad, D. W., C. L. Goad, and T. G. Nagaraja. 1998. Ruminal microbial and fermentative changes associated with experimentally induced subacute acidosis in steers. J. Anim. Sci. 76:234-241.

Griinari, J. M., K. Nurmela, D. A. Dwyer, D. M. Barbano, and D. E. Bauman. 1999. Variation of milk fat concentration of conjugated linoleic acid and milk fat percentage is associated with a change in ruminal biohydrogenation. J. Anim. Sci. 77(Suppl.):117-118. (Abstr.)

Hu, W., and M. R. Murphy. 2004. Dietary cation-anion difference effects on performance and acid-base status of lactating dairy cows: A meta-analysis. J. Dairy Sci. 87:2222-2229.

Hurtaud, C., H. Rulquin, and R. Vérité. 1993. Effect of infused volatile fatty acids and caseinate on milk composition and coagulation in dairy cows. J. Dairy Sci. 76:3011-3020.

Institut National de la Recherche Agronomique. 1989. Ruminant Nutrition: Recommended Allowances and Feed Tables. R. Jarrige, ed. John Libbey, Eurotext, London, UK.

Kalscheur, K. F., B. B. Teter, L. S. Piperova, and R. A. Erdman. 1997. Effect of dietary forage concentration and buffer addition on 
duodenal flow of trans-C18:1 fatty acids and milk fat production in dairy cows. J. Dairy Sci. 80:2104-2114.

Loor, J. J., and J. H. Herbein. 2001. Alterations in blood plasma and milk fatty acid profiles of lactating Holstein cows in response to ruminal infusion of a conjugated linoleic acid mixture. Anim. Res. 50:463-476.

Mertens, D. R. 1997. Creating a system of meeting the fiber requirements of dairy cows. J. Dairy Sci. 80:1463-1481.

Owens, F. N., W. J. Secrist, W. J. Hill, and D. R. Gill. 1998. Acidosis in cattle: A review. J. Anim. Sci. 76:275-286.

Peyraud, J. L. 2000. La dynamique de dégradation de l'énergie est un élément déterminant de la fibrosité des régimes. Renc. Rech. Rumin. 7:183-186.

Rigout, S., S. Lemosquet, A. Bach, J. W. Blum, and H. Rulquin. 2002. Duodenal infusion of glucose decreases milk fat production in grass silage fed dairy cows. J. Dairy Sci. 85:2541-2550.

Roche, J. R., S. Petch, and J. K. Kay. 2005. Manipulating the dietary cation-anion difference via drenching to early lactation dairy cows grazing pasture. J. Dairy Sci. 88:264-276.

SAS Institute. 1990. SAS User's Guide: Statistics. Version 6, ed 4. SAS Inst., Inc., Cary, NC.

Schotman, A. J. H. 1971. The acid-base balance in clinically healthy and diseased cattle. Neth. J. Vet. Sci. 4:5-24.

Stewart, P. A. 1983. Modern quantitative acid-base chemistry. Can. J. Physiol. Pharmacol. 61:1444-1452.
Tucker, W. B., J. F. Hogue, D. F. Waterman, T. S. Swenson, Z. Xin, R. W. Hemken, J. A. Jackson, G. D. Adams, and L. J. Spicer. 1991. Role of sulfur and chloride in the dietary cation-anion balance equation for lactating dairy cattle. J. Anim. Sci. 69:1205-1213.

Tucker, W. B., I. S. Shin, J. F. Hogue, M. Aslam, G. D. Adams, M. T. Van Koevering, R. K. Vernon, and K. R. Cummings. 1994. Natural sodium sesquicarbonate fed for an entire lactation: Influence on performance and acid-base status. J. Dairy Sci. 77:3111-3117.

Tucker, W. B., Z. Xin, and R. W. Hemken. 1988. Influence of dietary calcium chloride on adaptive changes in acid-base status and mineral metabolism in lactating dairy cows fed a diet high in sodium bicarbonate. J. Dairy Sci. 71:1587-1597.

Van Soest, J. P., J. B. Robertson, and B. A. Lewis. 1991. Methods of dietary fiber, neutral detergent fiber and nonstarch polysaccharides in relation to animal nutrition. J. Dairy Sci. 74:3583-3597.

Waterman, D. F., T. S. Swenson, W. B. Tucker, and R. W. Hemken. 1991. Role of magnesium in the dietary cation-anion balance equation for ruminants. J. Dairy Sci. 74:1866-1873.

West, J. W., K. D. Haydon, B. G. Mullinix, and T. G. Sandifer. 1992. Dietary cation-anion balance and cation source effects on production and acid-base status of heat-stressed cows. J. Dairy Sci. 75:2776-2786.

West, J. W., B. G. Mullinix, and T. G. Sandifer. 1991. Changing dietary electrolyte balance for dairy cow in cool and hot environments. J. Dairy Sci. 74:1662-1674. 